\title{
SOCIO-ECONOMIC PERFORMANCE OF A SOLAR FLAT PLATE COLLECTOR BASED IN A HEAT PUMP WATER HEATING SYSTEM IN THE BRAZILIAN SOUTHEAST
}

\author{
O. R. S. Rodríguez ${ }^{\mathrm{a}}$, \\ R. N. N. Koury ${ }^{b}$, \\ and A. A. T. Maia ${ }^{\mathrm{b}}$ \\ ${ }^{a}$ Universidade Federal de Minas Gerais \\ Departamento de Pós-graduação em \\ Engenharia Mecânica \\ Av. Pres. Antônio Carlos, 6627 - Pampulha \\ Belo Horizonte - MG, 31270-901, Brasil \\ ingpino@ufmg.br \\ ${ }^{b}$ Universidade Federal de Minas Gerais \\ Departamento de Engenharia Mecânica \\ Av. Pres. Antônio Carlos, 6627 - Pampulha \\ Belo Horizonte - MG, 31270-901, Brasil \\ koury@demec.ufmg.br \\ Received: April 02, 2016 \\ Revised: May 13, 2016 \\ Accepted: June 15, 2016
}

\begin{abstract}
By increasing renewable energy demand, the use of solar energy has been widely investigated over the recent years. Brazil is a privileged country in terms of the levels of receivable solar radiation in almost all over its territory. However, as there are days when there is a deficit in solar energy, because the day be cloudy or rainy days, and for this reason, solar collectors need a support to contribute to the water heating to the desired temperature. In this work, an experimental study of a heat pump operated with R-134a, as an ancillary equipment for a solar water heating system in Belo Horizonte city has been accomplished. For this project, is used a set of electrical resistances for by a power control step, simulate historical annual values of solar radiation. In the results, it was observed that is achieved through the collection of solar energy the temperature of $45^{\circ} \mathrm{C}$ in the reservoir only in January, and the other eleven months is necessary to use the heat pump to achieve reach that temperature. With the heat pump operating in conditions similar to real conditions gave an average annual consumption of $137.65 \mathrm{kWh}$ and a cost of $\mathrm{R} \$ 60.61$.
\end{abstract}

Keywords: simulation, water heating, fabrication, solar collector

\section{NOMENCLATURE}

BDD Heat Pump Database

COP coefficient of performance

d day

D digital output module

HP-SE heat pump with solar evaporator system

I hourly radiation, $\mathrm{MJm}^{-2}$

$\mathrm{k}_{\mathrm{t}} \quad$ hourly clearness index

M month

$\mathrm{n} \quad$ day simulated (0-365)

$\mathrm{N}$ number of daylight hours

$\mathrm{P}$ power, $\mathrm{W}$

$\mathrm{r} \quad$ reflectivity

$\mathrm{R}_{\mathrm{B}} \quad$ direct radiation rate on the inclined plane

$\mathrm{R} \$ \quad$ Real - the present-day currency of Brazil

$\mathrm{S} \quad$ Solar radiation absorbed, $\mathrm{MJm}^{-2}$

$\mathrm{T}$ temperature, $\mathrm{K}$

$\mathrm{V}$ voltage, $\mathrm{V}$

$\mathrm{Z} \quad$ constant programming

\section{Greek symbols}

$\alpha \quad$ absorptance or absorption power

$\beta \quad$ collector slope, ${ }^{\circ}$

$\varphi \quad$ latitude, ${ }^{\circ}$

$\delta \quad$ declination

$\theta \quad$ angle between surface normal and incident radiation

$\begin{array}{ll}\rho & \text { reflectance } \\ \tau & \text { transmittance } \\ \omega & \text { hour angle }\end{array}$

\section{Subscripts}

$\begin{array}{ll}1 & \text { after hour or output1 } \\ 2 & \text { before hour or output2 } \\ \text { a } & \text { ambient, absorbed } \\ \text { ag } & \text { water } \\ \text { b } & \text { direct } \\ \text { d } & \text { beam } \\ \text { g } & \text { ground } \\ \text { n } & \text { normal } \\ \text { r } & \text { radiation }\end{array}$

\section{INTRODUCTION}

The growth in the human population, as well as the access to better life conditions, is making energetic demand to be bigger every day (Owen, Inderwildi and King, 2010). In the last years, however, concerns have been growing due to two factors: the environmental impacts of burning large amounts of fossil fuels and the lack of knowledge regarding meeting the growing demand on current global reserves (Campbell and Laherrère, 1998; Alekkett, 2007; Robelius, 2007; Laherrére, 2009). Driven by these facts, NGOs are working to increase 
the contribution of renewable energy sources and, therefore, reduce the consumption of such fuels, which will contribute to reduce the problems mentioned before (Ibrahim et al., 2014).

On the other hand, a significant share of the total energy produced in the world is used for domestic water heating, that share being $11 \%$ in the United States of America (Levine et al., 2007), 14\% in Europe (ADEME, 2009 ), 22\% in Canada (Aguilar, White and Ryan, 2005), 25\% in Australia (Government, 2013), 24\% in Brazil (Dos Santos et al., 2011), 29\% in Mexico (Rosas-Flores, RosasFlores and Gálvez, 2011), 27\% in China (Zhou et al., 2008) and 32\% in South Africa (Accounts, 2005).

As a way of reducing this consumption in Brazil and also contributing to the usage of renewable energy sources, solar domestic water heating devices are being used (Sandoval, O. R., 2015). However, a restriction for the use of such systems on their own is the lack of sunny days throughout the year. Because of that, this paper discusses the results obtained with equipment made of a solar collector simulator and a heat pump with a static evaporator (HP-SE) designed as an auxiliary system with the intent of characterizing a low cost system for Brazilian families.

\section{SYSTEM DESCRIPTION}

The suggested system design parameters were thoroughly discussed in previous papers and are illustrated in Fig. 1a (De Melo Reis et al., 2012). Three main systems can be seen: the water reservoir, with a capacity of 2001 , the solar collector simulator system and the HP-SE. The simulating system is a modular system, made of 8 copper tubes with a diameter of $3 / 8$ " disposed in parallel in which water flows naturally (thermosiphon effect), which, through computational calculations, converts available solar radiation date into the equivalent heat flow that must be transferred to the water with the aid of the electrical resistances coiled around the tube (Fig. 1b). The heat pump operating with $\mathrm{R} 134 \mathrm{a}$ is made of a piston type hermetic alternative compressor from Embraco, model FFV 100 HAK, a water based condenser made with $3 / 8$ " copper tubes that are submerged for $4.5 \mathrm{~m}$ in the reservoir, a static evaporator made from 3/8" tubes with a length of 16 $\mathrm{m}$ and a thermostatic expansion device from Danfoss TEN 2- orifice NROX.

Through experimental testing, the operational performance of the thermal support equipment has been characterized (Sandoval, O. R., et al., 2014a; Sandoval, O. R. et al., 2014b) with the following conclusions, respectively: (1) Firstly, two set-ups for the heat pump were studied: HP-SE and HP-CE (conventional evaporator). The HP-SE system turned out to be the one with the best efficiency; (2) the system with the static evaporator presented a COP of 2.15; (3) according to the financial analysis tool, IRR (internal rate of return) and the return over the own capital, the solar energy system combined to the HPSE presented values over $24,5 \%$, as well as the fact that the return over the investment was shorter than 3.6 years; and (4) the average time spent to raise the water temperature from $35^{\circ} \mathrm{C}$ to $45^{\circ} \mathrm{C}$, without any radiation, was 220 minutes.

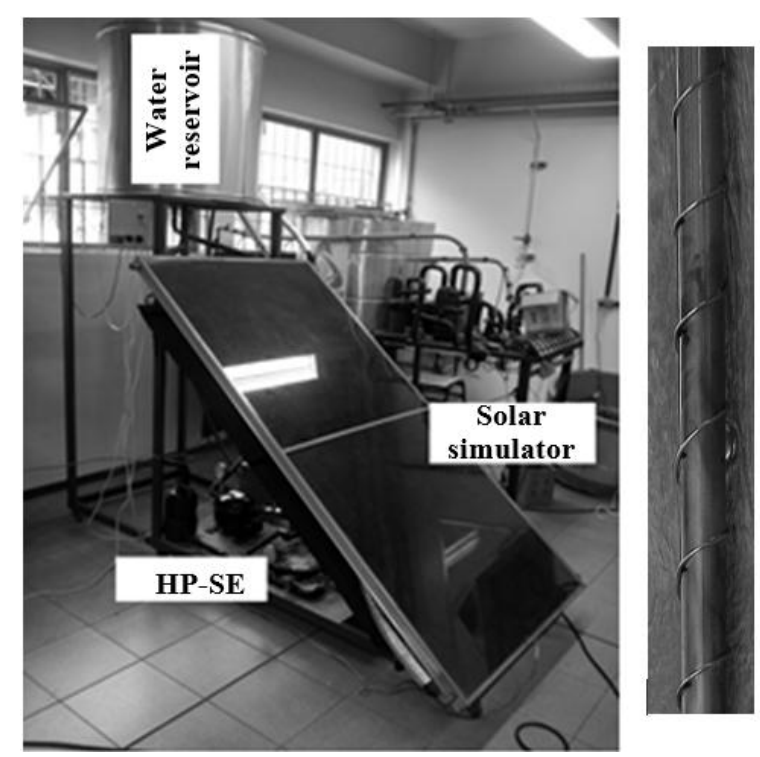

Figure 1. (a) Schematic of the solar equipment water heating system (HP-SE) (b) Resistance configuration.

\section{MATHEMATICAL MODEL AND SIMULATION}

The Figure 2 and 3 show the initial values conditions and the behaviors for the solar global radiation, the ambient temperature of the air and the water (Tab. 1) were obtained using the software Radiasol2 using the database for the Minas Gerais' capital city $\left(19^{\circ} 49^{\prime} 1^{\prime} ' \mathrm{~S}, 43^{\circ} 57^{\prime} 21^{\prime \prime} \mathrm{W}\right)$ (LABSOL, 2014). The Figure 4 details the process used by the computational algorithm. During the simulation day, the operation of the equipment began at 08:00 am and stopped at 07:00 pm.

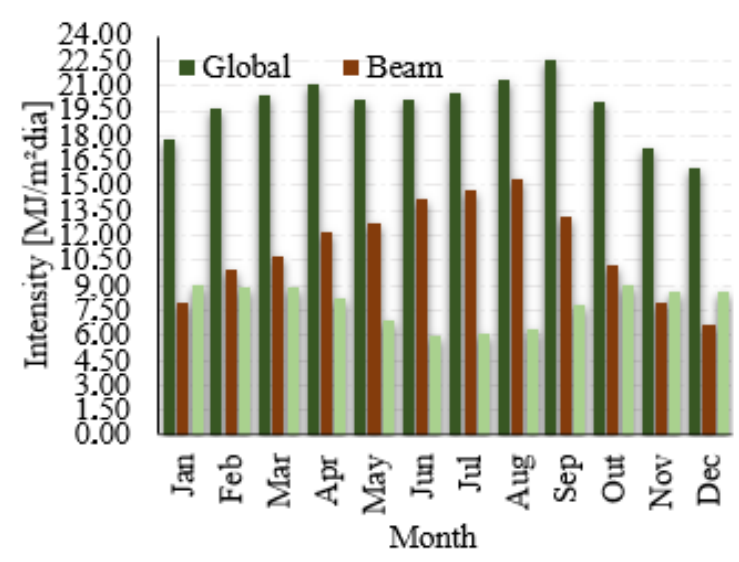

Figure 2. Monthly averages for solar radiation in Belo Horizonte, collector slope $36^{\circ} \mathrm{N}$. 


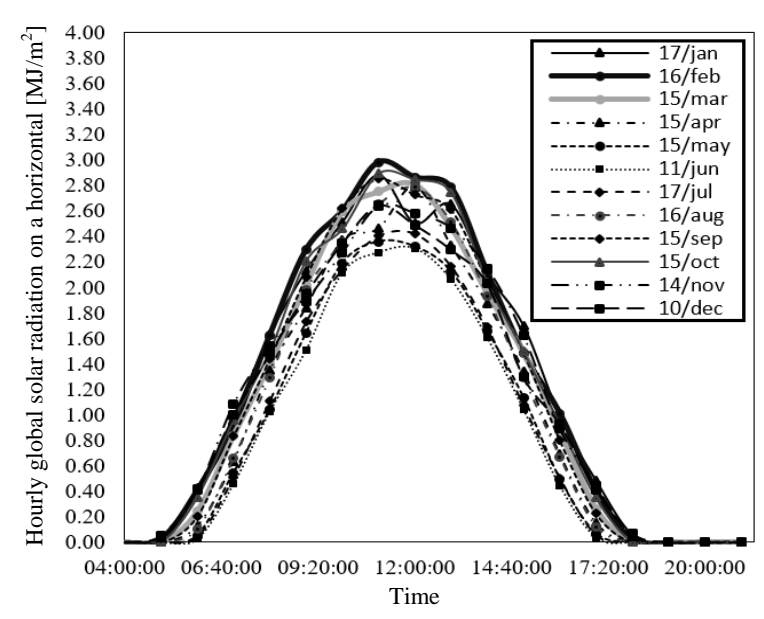

Figure 3. Hourly global solar radiation on the horizontal.

The HP-SE was set to begin working only after 05:00 pm and only when the temperature inside the reservoir got under $45^{\circ} \mathrm{C}$ in any month of the year. The control algorithms for the solar collector and the HP-SE are presented in the flux diagrams in Fig. 5 and 6.

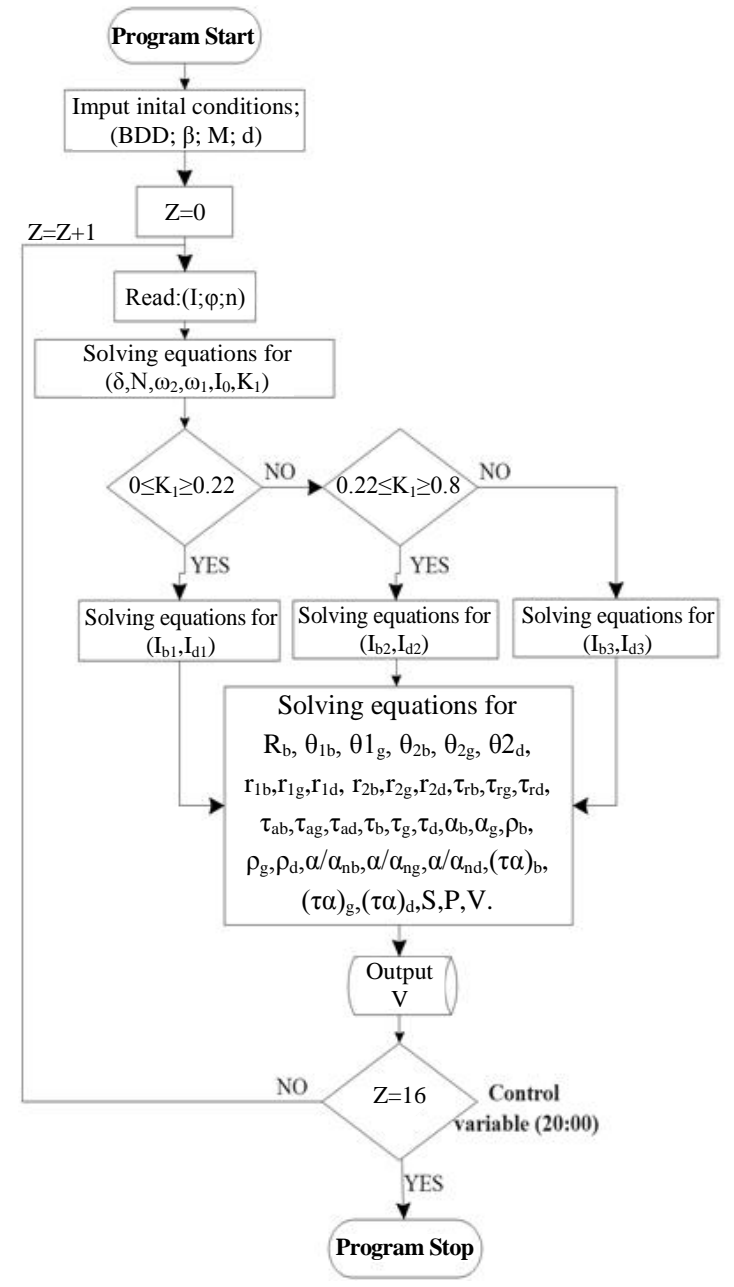

Figure 4. Algorithm 1 (Main software). Solar collector simulator.

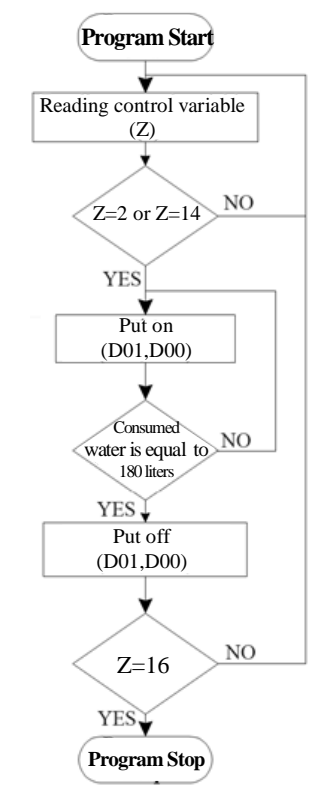

Figure 5. Algorithm 2. Consumption residential water in a simple day.

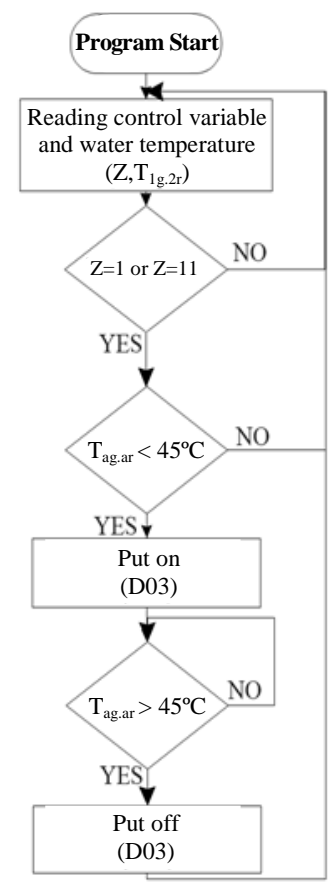

Figure 6. Algorithm 3. Auxiliary control system.

Table 1. Monthly averages for ambient and water temperature in Belo Horizonte $\left[{ }^{\circ} \mathrm{C}\right]$.

\begin{tabular}{|c|c|c|}
\hline Month & $\begin{array}{r}\text { Temperature ambient } \\
{\left[{ }^{\circ} \mathrm{C}\right]}\end{array}$ & $\begin{array}{c}\text { Temperature } \\
\text { Water } \\
{\left[{ }^{\circ} \mathrm{C}\right]}\end{array}$ \\
\hline Jan & 23.1 & 26.5 \\
\hline Feb & 22.6 & 26.0 \\
\hline Mar & 23.0 & 26.4 \\
\hline Apr & 22.1 & 25.5 \\
\hline May & 20.3 & 23.7 \\
\hline Jun & 18.1 & 21.5 \\
\hline Jul & 18.9 & 22.3 \\
\hline
\end{tabular}




\begin{tabular}{|c|c|c|}
\hline Aug & 20.2 & 23.6 \\
\hline Sep & 20.7 & 24.1 \\
\hline Oct & 22.8 & 26.2 \\
\hline Nov & 22.9 & 26.3 \\
\hline Dec & 21.8 & 25.2 \\
\hline
\end{tabular}

\section{RESULTS AND DISCUSSION}

\section{Test Methodology}

In order to compare results, the following test was done on the system: water heating through the collector simulating the seasonal radiations that are representative for the city of Belo Horizonte. When the temperature of the stored water does not meet the user demands (equal to or above $45^{\circ} \mathrm{C}$ ) the HP-SE will start working in order to raise the water temperature to $45^{\circ} \mathrm{C}$.

For each of the situations described above, the values of the temperature were obtained (ambient, collector inlet, interior and outlet, water reservoir interior, compressor inlet and outlet, condenser outlet, static evaporator inlet), as well as the power consumption of the HP-SE, the amount of time the auxiliary system worked and the pressure (compressor inlet and outlet, condenser outlet and static evaporator inlet).

In the measures taken in the refrigerant fluid circuit, the influence of the lubricant oil is taken in account by mixing it with the refrigerant fluid. According to Dang et al. (2007) and Al-Rashed (2011) the measurements of compression power and pressure have a significant increase due to the flow of oil-refrigerant mixture, and this is why a decrease in the refrigeration system's COP can be seen.

\section{Result and analysis}

The evaluation of the data made it possible to illustrate, in Fig. 7, the monthly average daily global radiation in the horizontal reaching the simulated panel.

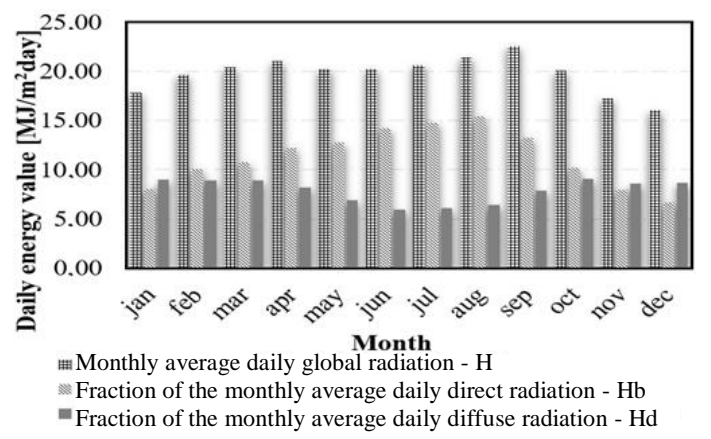

Figure 7. Global radiation, diffuse fraction and direct fraction of the monthly average daily direct radiation.

The hourly thermal behavior of the water is illustrated in Fig. 8. It is possible to see that the biggest change in the temperature always occurred between the hours of $11 \mathrm{am}$ and $3 \mathrm{pm}(15 \mathrm{~h})$, since during this time of the day the collector was absorbing the biggest amount of solar radiation. It is also possible to notice that during the months of February, March, April, May and September, the temperature of the water reached $40^{\circ} \mathrm{C}$, which can be considered as bathing suitable.

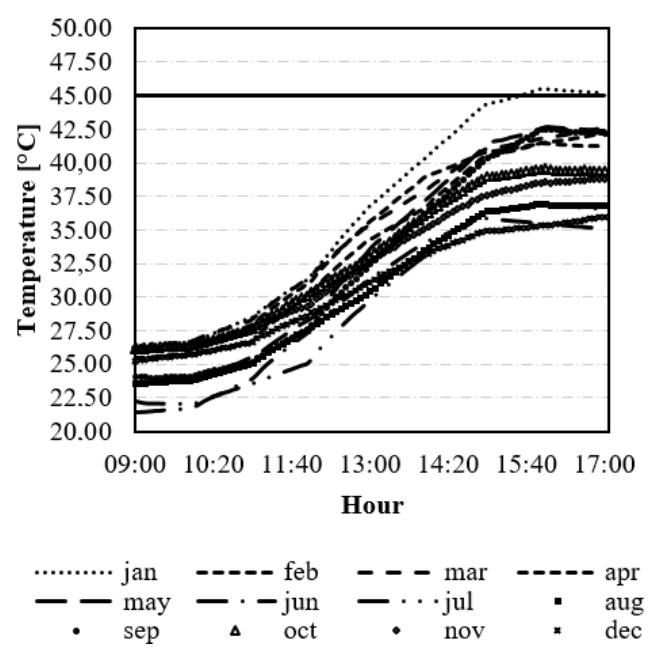

Figure 8. Temperature in the tank (200 1) during the simulation.

The lowest temperatures occurred in the months of June, July, August and December, and did not go above $37^{\circ} \mathrm{C}$. The lowest registered temperature occurred in the month of June, during which water got to a maximum of $35^{\circ} \mathrm{C}$ and the work required from the HP-SE would not be bigger than the required to raise the temperature another $10^{\circ} \mathrm{C}$.

The average energy consumption for the HP-SE (in $\mathrm{kWh}$ ) during each month, in the city of Belo Horizonte, is illustrated in Fig. 9. The device successfully raised the temperature of the stored water to $45^{\circ} \mathrm{C}$. Tab. 2 shows the possible average monthly consumption for the prototype in the city of Belo Horizonte.

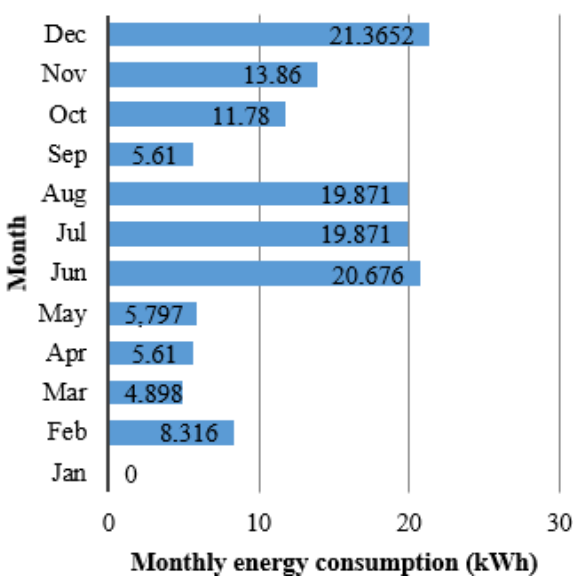

Figure 9. Average monthly energy consumption for the HP in the city of Belo Horizonte. 


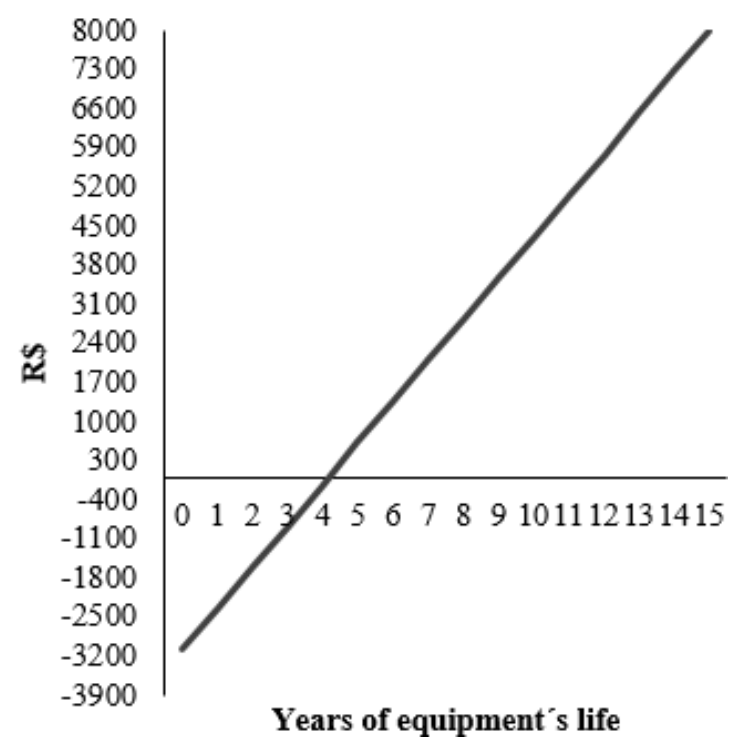

Figure 10. Projection of the cash flow during a lifespan of 15 years.

Table 2. Average monthly cost of the energy used by the HP working as an auxiliary system.

\begin{tabular}{|c|c|c|c|}
\hline \multirow[b]{2}{*}{ Month } & \multicolumn{3}{|c|}{ Cost } \\
\hline & $\begin{array}{c}\text { HP-SE } \\
\text { (Auxiliary system) }\end{array}$ & $\begin{array}{c}\text { Electric } \\
\text { resistance } \\
\text { (Auxiliary } \\
\text { system) }\end{array}$ & $\begin{array}{c}\text { Electric } \\
\text { resistance } \\
\text { (Main } \\
\text { system) }\end{array}$ \\
\hline Jan & $\mathrm{R} \$ 0.00$ & $\mathrm{R} \$ 0.00$ & $\mathrm{R} \$ 62.02$ \\
\hline $\mathrm{Feb}$ & $\mathrm{R} \$ 3.67$ & $\mathrm{R} \$ 10.75$ & $\mathrm{R} \$ 57.53$ \\
\hline Mar & $\mathrm{R} \$ 2.16$ & $\mathrm{R} \$ 7.91$ & $\mathrm{R} \$ 62.52$ \\
\hline Apr & $\mathrm{R} \$ 2.47$ & $\mathrm{R} \$ 9.28$ & $\mathrm{R} \$ 63.26$ \\
\hline May & $\mathrm{R} \$ 2.56$ & $\mathrm{R} \$ 8.82$ & $\mathrm{R} \$ 71.58$ \\
\hline Jun & $\mathrm{R} \$ 9.13$ & $\mathrm{R} \$ 32.16$ & $\mathrm{R} \$ 76.41$ \\
\hline Jul & $\mathrm{R} \$ 8.77$ & $\mathrm{R} \$ 28.34$ & $\mathrm{R} \$ 76.27$ \\
\hline Aug & $\mathrm{R} \$ 8.77$ & $\mathrm{R} \$ 27.44$ & $\mathrm{R} \$ 71.74$ \\
\hline Sep & $\mathrm{R} \$ 2.47$ & $\mathrm{R} \$ 8.93$ & $\mathrm{R} \$ 67.97$ \\
\hline Oct & $\mathrm{R} \$ 5.20$ & $\mathrm{R} \$ 18.88$ & $\mathrm{R} \$ 63.20$ \\
\hline Nov & $\mathrm{R} \$ 6.12$ & $\mathrm{R} \$ 20.29$ & $\mathrm{R} \$ 60.83$ \\
\hline Dec & $\mathrm{R} \$ 9.43$ & $\mathrm{R} \$ 31.46$ & $\mathrm{R} \$ 66.38$ \\
\hline $\begin{array}{l}\text { Year } \\
(\mathrm{NT})\end{array}$ & $\mathrm{R} \$ 60.61$ & $\mathrm{R} \$ 204.26$ & $\mathrm{R} \$ 799.71$ \\
\hline \multicolumn{2}{|c|}{$\mathrm{R} \$ 0.441564$} & \multicolumn{2}{|c|}{$\begin{array}{c}\text { Cemig's residential fee } \\
(\text { No Taxes - NT) }\end{array}$} \\
\hline
\end{tabular}

The average monthly consumption of the device in the city of Belo Horizonte was $137.65 \mathrm{kWh}$ with a cost of R\$ 60.61, that value being projected from the consumption and the residential fee (Cemig, 2015). This is an interesting value when compared to the cost of using an electric resistance as an auxiliary system, which is of $\mathrm{R} \$ 204.26$ and the cost of using the electric resistance as the main heating system, something commonly done in Brazil, which is of $\mathrm{R} \$$ 799.71

The calculations of the financial feasibility and the cash flow (Fig. 10) present positive IRR values, greater than $20 \%$, as well as a return of the investment in less than 4.2 years, which is an adequate period of time for such investment.

The Table 3 shows the values of the COP evaluated in each of the eleven tests done for the water heating.

Table 3. Global COP for the Heat Pump.

\begin{tabular}{|c|c|}
\hline Month & COP \\
\hline Feb & 1.58 \\
\hline Mar & 2.06 \\
\hline Apr & 1.82 \\
\hline May & 1.86 \\
\hline Jun & 2.21 \\
\hline Jul & 1.87 \\
\hline Aug & 2.05 \\
\hline Sep & 1.88 \\
\hline Oct & 2.54 \\
\hline Nov & 1.40 \\
\hline Dec & 2.04 \\
\hline Average & 1.88 \\
\hline
\end{tabular}

Lastly, as in the research done by De Melo Reis, R. V. (2012), it is possible to notice a decrease in the COP of the equipment as the water temperature raises. Fig. 11 shows this behavior for the month of July, but it was noticed that the pattern remains the same throughout the year.

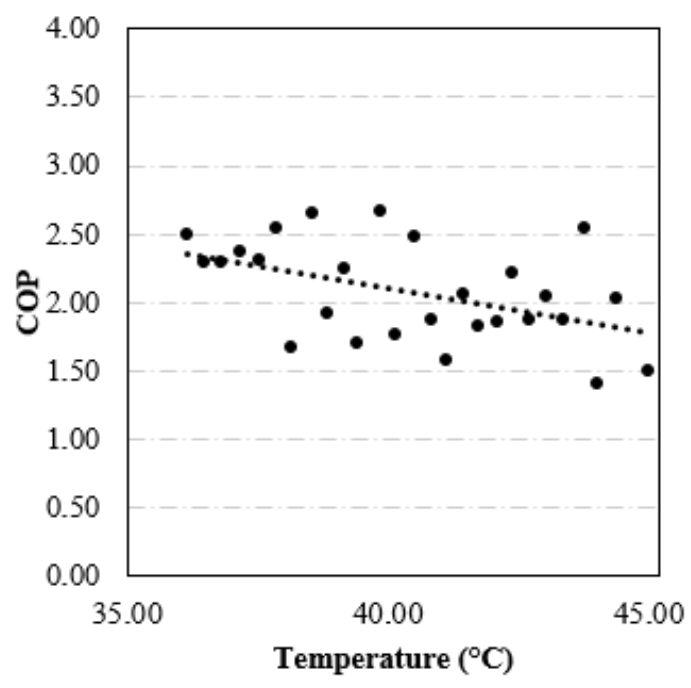

Figure 11. Average consumption of the HP in $\mathrm{kWh}$ during the month of July in the city of Belo

Horizonte.

The decrease in the COP is due to the heating of the water in the reservoir. This causes the pressure difference in the compressor to increase, which influences directly causing a reduction in its volumetric efficiency, thus requiring more compression work and reducing the system efficiency.

\section{CONCLUSIONS}

The energy losses can be associated mostly with the solar collector inclination and the low ambient 
temperatures registered in the city during some months. According to this paper, the correct use of the inclination allows for more energy to be absorbed during the months in which it is most required, as is the case in the winter.

Through the simulation of the historic solar data, January can be seen as a special month, because during the whole month there is no need for the use of an auxiliary mechanism.

The water temperature in the months of February, March, April, May and September could be considered as within human comfort zone, since during these months the temperature was between $40^{\circ} \mathrm{C}$ and $43^{\circ} \mathrm{C}$.

The heat pump operating in conditions similar to the real ones consumed an annual average of $137.65 \mathrm{kWh}$ and had an average cost of $\mathrm{R} \$ 60.61$.

Lastly, the results of this paper showed that it is possible to develop reliable solar simulators, which can be used for the study of the behavior and characteristics of new support systems. Additionally, the use of mathematical models and historical solar radiation databases as appropriate tools for the characterization of an auxiliary prototype should be emphasized.

\section{ACKNOWLEDGEMENTS}

The authors of this paper would like to thank Maxtemper company (www.maxtemper.com.br) and the Conselho Nacional de Desenvolvimento Científico e Tecnológico (CNPq), without which this research would not have been possible.

\section{REFERENCES}

Accounts, N. R., 2005, Energy Accounts for South Africa, in: Africa, S. S. Natural Resource Accounts.

ADEME, 2009, Energy Efficiency Trends and Policies in the Household \& Tertiary Sectors in the EU 27. Agence de l'Environnement et la Maitrise de l'Energie, the ODYSSEE/MURE project.

Aguilar, C., White, D., and Ryan, D. L., 2005, Domestic Water Heating and Water Heater Energy Consumption in Canada, Canadian Building Energy, End-Use Data and Analysis Centre.

Al-Rashed, A. A. A. A., 2011, Effect of Evaporator Temperature on Vapor Compression Refrigeration System, Alexandria Engineering Journal, Vol. 50, No. 4, pp. 283-290.

Alekkett, K., 2007, Peak Oil and the Evolving Strategies of Oil Importing and Exporting Countries, Oil Dependence: is Transport Running out of Affordable Fuel, pp. 37-114.

Campbell, C. J., and Laherrère, J. H., 1998, The End of Cheap Oil, Scientific American, Vol. 278, No. 3, pp. 60-65.

Dang, C. B., Hoshika, K., and Hihara, E., 2007, Effect of Lubricating Oil on Cooling Heat Transfer of
Supercritical Carbon Dioxide, International Journal of Refrigeration, Vol. 30, No. 4, pp. 724-731.

De Melo Reis, R. V., Oliveira, R. N., Machado, L., and Koury, R. N. N., 2012, Using a Heat Pump as an Alternative to Support Solar Collector of Water Heating in Brazil, International Journal of AirConditioning and Refrigeration, Vol. 20, No. 3, pp. 1250013.

De Melo Reis, R. V., 2012, Comparative Experimental Analysis of a Heat Pump and an Electric Resistance as Energy Support System for a Solar Water Heater, Doctoral Thesis, Universidade Federal de Minas Gerais, Belo Horizonte, MG. (in Portuguese)

Dos Santos, M. J., dos Santos, M. A., Salvador, E., dos Santos, G. C., Siqueira, M. C., David, R. M., Ficara, R., and Rosito, L. H., 2011, Solar Heating Systems Evaluation in Low-Income Households, in: XXI SNPTEE National Seminar on Production and Electricity Transmission, Florianópolis, SC.

Government, A., 2013, State of Australian Cities 2013, in: Transport, D. o. I. a.: Major Cities Unit, Infrastructure Australia.

Ibrahim, O., Fardoun, F., Younes, F., and Louahlia-Gualous, H., 2014, Review of WaterHeating Systems: General Selection Approach Based on Energy and Environmental Aspects, Building and Environment, Vol. 72, pp. 259-286.

LABSOL, 2014, RADIASOL2 Software, Universidade Federal do Rio Grande do Sul, Porto Alegre, RS.

Laherrére, J., 2009, Oil Peak or Plateau, in: $S t$ Andrews Economy Forum.

Levine, M., 2007, Residential and Commercial Buildings, in: Cambridge University Press, C., United Kingdom and New York, NY, USA. (Ed.). Climate Change 2007: Mitigation, Contribution of Working Group III to the Fourth Assessment Report of the Intergovernmental Panel on Climate Chang.

Owen, N. A., Inderwildi, O. R., and King, D. A., 2010, The Status of Conventional World Oil Reserves-Hype or Cause for Concern?, Energy Policy, Vol. 38, pp. 4743-4749.

Robelius, F., 2007, Giant Oil Fields-the Highway to Oil: Giant Oil Fields and Their Importance for Future Oil Production, Uppsala Dissertations from the Faculty of Science \& Technology.

Sandoval, O. R., 2015, Development of a Solar Collector Simulator for Reproducing the Operating Conditions of a Heat Pump for Domestic Water Heating, Master Thesis, Universidade Federal de Minas Gerais, Belo Horizonte, MG. (in Portuguese)

Sandoval, O. R., 2014a, Heat Pump in Support of a Solar Collector System for Residential Water Heating, in: VIII National Congress of Mechanical Engineering, Uberlândia, MG. (in Portuguese)

Sandoval, O. R., 2014b, Comparison Experimental Between a Conventional and a Solar Evaporator of a Heat Pump Supporting a Solar 
Collector, in: V Brazilian Congress of Solar Energy, Recife, PE. (in Portuguese)

Rosas-Flores, J. A., Rosas-Flores, D., and Gálvez, D. M., 2011, Saturation, Energy Consumption, $\mathrm{CO}_{2}$ Emission and Energy Efficiency from Urban and Rural Households Appliances in Mexico, Energy and Buildings, Vol. 43, No. 1, pp. 10-18.

Zhou, N, McNeil, M. A., Fridley, D., Lin, J., Price, L., de la Rue du Can, S., Sathaye, J., and Levine, M., 2008, Energy use in China: Sectoral Trends and Future Outlook, Lawrence Berkeley National Laboratory. 